\title{
Smoking during adolescence and the harm reduction model as an alternative intervention
}

\author{
Tabaquismo en la adolescencia y el modelo de reducción del daño como alternativa de \\ intervención
}

\author{
Brenda E. Barraza-Sánchez ${ }^{a}$
}

\begin{abstract}
:
Introduction: Smoking is one of the main public health problems in the world, due to the fact that every year more than eight million people die from tobacco use. During adolescence, three out of five tobacco users generate an addiction. Objective: To carry out a systematic review to help understand the smoking phenomenon during adolescence and the effectiveness of the harm reduction model as a treatment for this population group. Method: A systematic review was executed, in the databases of PubMed, Ebsco, Dialnet, ScienceDirect, and Redalyc, as well as documents issued by public and governmental institutions and organizations. Using the following keywords: smoking, adolescence, and harm reduction. Results: Out of the 43 consulted sources; they were detected in PubMed (46\%), Ebsco (11\%), Dialnet (10\%), ScienceDirect (7\%), Redalyc (13\%) and official pages (13\%). Out of the 13 reviewed scientific articles that report the effectiveness of the harm reduction model for the treatment of tobacco use among adolescents, nine conclude that this approach contributes to the treatment of adolescents who wish to stop using tobacco, while four researches conclude that there are no significant changes, and that this type of treatment may cause adverse effects. Conclusions: The harm reduction model as intervention for the reduction of risks caused by the consumption of substances, including tobacco, has shown favourable results, however, there are few researches with adolescent population that consume tobacco which show the effectiveness of set intervention.
\end{abstract}

Keywords:

smoking, adolescence, harm reduction model

\section{Resumen:}

Introducción: El tabaquismo es uno de los principales problemas de salud pública en el mundo, debido a que cada año más de ocho millones de personas mueren a causa del consumo de tabaco. Durante la adolescencia tres de cada cinco consumidores de tabaco generan una adicción. Objetivo: Realizar una revisión sistemática que permita conocer el fenómeno del tabaquismo en la adolescencia y la eficacia del modelo de reducción de daños como tratamiento para este grupo poblacional. Método: Se realizó una revisión sistemática, en las bases de datos PubMed, Ebsco, Dialnet, ScienceDirect y Redalyc, así como documentos emitidos por instituciones y organizaciones públicas y gubernamentales. Utilizando las siguientes palabras clave: tabaquismo, adolescencia, reducción de daños. Resultados: De las 43 fuentes consultadas, se detectaron en PubMed (46\%), Ebsco (11\%), Dialnet (10\%), ScienceDirect (7\%), Redalyc (13\%) y páginas oficiales (13\%). De los 13 artículos científicos revisados que reportan evidencia de la eficacia del modelo de reducción de daño para el tratamiento de consumo de tabaco en adolescentes, nueve concluyen que este enfoque coadyuva al tratamiento de adolescentes que desean dejar de consumir tabaco, mientras que cuatro investigaciones refieren que no hay cambios significativos, y que este tipo de tratamiento puede causar efectos adversos. Conclusiones: El modelo de reducción de daños como intervención para la disminución de riesgos por consumo de sustancias, incluyendo el tabaco, ha mostrado resultados favorables, sin embargo, son pocas las investigaciones con población adolescente que consume tabaco que demuestren la eficacia de dicha intervención.

\section{Palabras Clave:}

Tabaquismo, adolescencia, modelo de reducción del daño 


\section{INTRODUCTION}

Smoking is an epidemic that represents one of the main public health problems in the world, due to the health and social consequences that implies for consumers. ${ }^{1}$

The tobacco comes from the NicotianaTabacum plant; which is native to America. Its main chemical component is nicotine (C10 H14 N2), a colorless and oily liquid alkaloid that has a double effect, one of them is that it stimulates and the other is that it acts as a sedative. Nicotine is precisely the main responsible for tobacco addiction, because it activates the dopaminergic pathway, as well as the cholinergic and nicotinic receptors of the central nervous system, generating a pleasant sensation, this stimulus is followed by depression and fatigue, which leads the addict to administer more nicotine, both to obtain the desired effects, such as pleasure or performance improvement. ${ }^{2}$

\section{EPIDEMIOLOGICAL OVERVIEW OF TABAQUISM}

\section{Worldwide}

According to the World Health Organization [WHO], more than 8 million people die from causes related to tobacco use each year., 7 million of these deaths are from direct use, and about 1.2 million are from inadvertent exposure to tobacco smoke. ${ }^{3}$ Every ten seconds a person dies in the world due to pathologies related to tobacco consumption, which is why it is considered the main preventable cause of disease, disability and premature death. ${ }^{4}$

Eighty percent of the world's youth live in developing countries, and an estimated 80,000 to 100,000 people in this age group become addicted to tobacco every day. ${ }^{5}$ Three out of five adolescents who try tobacco develop an addiction to it during adulthood. ${ }^{6}$

The WHO report on trends in the prevalence of tobacco use 2020-2025 indicates that, in 2018, approximately 43 million adolescents between 13 and 15 years old used tobacco, with 14 million being women and 29 million being men. Regarding the consumption trend in the Americas, it is the region with the best performance with respect to reaching the goal of reducing tobacco consumption by $2030 .^{7}$

According to current trends, it is estimated that in the year 2020 more than 10 million people will die from tobacco, half of them in a productive age, with an individual loss of 10 to 20 years of life, while in 2030 seven out of 10 of these frequent deaths will be in developing countries. ${ }^{2}$

\section{National}

In Mexico, approximately $10 \%$ of smokers start smoking before 11 years old, $50 \%$ between 15 to 17 years of age, which means that seven out of 10 tobacco users try their first cigarette before 18 years old, curiosity being the main reason for consumption or having the influence of an smokers environment, especially within the family and the influence of friends. ${ }^{8}$

Two of the fundamental tools for epidemiological surveillance of tobacco use in Mexico refer to the Global Survey on Adult Smoking ${ }^{9}$ and the Youth Tobacco Survey [ETJ] which allow us to visualize the epidemiological panorama of the prevalence of tobacco consumption in these age groups. ${ }^{5}$

According to the Global Survey on Smoking in Adults carried out in 2015, the global prevalence of smoking in adults was $16.4 \%$ of the total smokers, $7.6 \%$ did it daily and $8.8 \%$ are occasional smokers, on average, men smoke 8 cigarettes and women 6.8 cigarettes per day. The average age of onset of tobacco use among daily smokers between 20 and 34 years was 16.5 years. Among this age group, $22.1 \%$ started smoking daily before the age of $15,33 \%$ between the ages of 15 and $16,30.1 \%$ between the ages of 17 and 19 , and $14.8 \%$ at the age of 20 or older. ${ }^{9}$

The National Survey on Drug, Alcohol and Tobacco Use, allows us to broaden the epidemiological panorama and consider sociodemographic factors regarding drug use. The most recent edition was carried out in 2016, where a comparison of tobacco consumption was reported in a population between 12 and 17 years of age, where it was found that in 2011, 10.5 million people in this age range had never used tobacco, while for 2016 the figure was 10.8 million, showing that, there was a decrease in consumption between these periods, when talking about the number of smokers in 20111.7 million were reported, and during 20161.1 million. ${ }^{1}$

\section{FACTORS ASSOCIATED WITH TOBACCO CONSUMPTION IN ADOLESCENCE}

Adolescence is undoubtedly a period in which the subject experiences a series of physiological and psychological changes that increase vulnerability to the adoption of risky behaviours that are linked to various factors. ${ }^{6}$ Numerous investigations have determined that there are a series of psychosocial factors related to tobacco consumption, In figure 1 it is possible to observe some of the most important factors to consider in various environments in which adolescents are identified. . $^{50}$

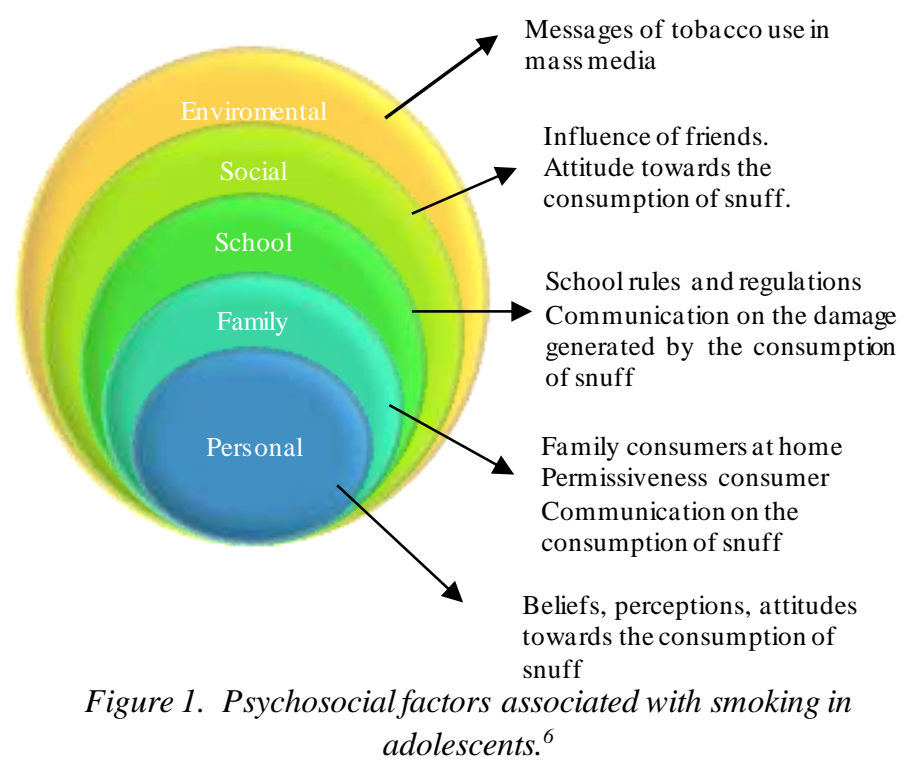

These factors can be clearly translated into figures thanks to the data provided by the Youth Tobacco Survey that indicated that exposure to second-hand smoke is a fundamental risk factor for adolescents, which not only makes them more prone to smoking. tobacco, but can cause serious health complications, a third of the participants in this survey, $33.3 \%$ reported being exposed to tobacco smoke inside their home and $44.6 \%$ of them, continue to be exposed to second-hand tobacco smoke in public places. 
$32.1 \%$ indicated that one or both of their parents smoked. 15.9\% reported that some of their best friend's smoke. ${ }^{5}$

According to research carried out with adolescents who use tobacco, it is a risk factor to be a man. ${ }^{11}$ Since when smoking is related to sex, it is stated that men have always been the greater consumers of cigarettes and tobacco products, which is associated with sociocultural factors such as machismo, which is an example of the customs and traditions of certain cultures, that have made cigarettes synonymous of masculinity, contributing to men following these ideals from early ages. ${ }^{4}$

It is of utmost importance to consider the risk factor that refers to the free access of young people to tobacco products, since the ETJ reveals that $65.1 \%$ of those surveyed between 13 and 15 years old were not denied the sale of tobacco because they are minors. $^{3}$

\section{CONSEQUENCES OF THE USE OF TOBACCO}

In Mexico, 135 people die every day from tobacco use. In 2017, more than 310 thousand new cases of pulmonary, cardiac, cerebrovascular diseases, and various cancers such as stomach, pancreas, liver and bladder cancer directly related to the consumption of this product, were registered. ${ }^{8}$

Regarding the knowledge of the consequences of tobacco consumption, in Mexico, $98 \%$ of 15 year old or older consumers know that smoking can develop a serious disease. Ninety seven point nine percent are aware that tobacco causes lung cancer, $83.6 \%$ that it causes acute myocardial infarction and $68 \%$ know that tobacco use can cause a stroke. ${ }^{9}$

Some of the short-term physiological effects are related to a weak immune system, in addition to lowering the leukocyte concentrations of vitamin $\mathrm{C}$, uric acid, serum, and albumin, as the ratio between high- and low-density lipoprotein cholesterol is lower. An obvious sign that identifies smokers are facial wrinkles and severe cases of teenage acne. ${ }^{2}$

In addition to physical ailments, tobacco is associated with mental disorders such as depression, which is related to nicotine dependence and is generally aggravated when the person wants to quit smoking, which shows during the withdrawal period, causing this process to be complicated due to the relapses. ${ }^{12}$

The same adolescents identify long-term effects such as a decrease in sports performance, in addition to serious conditions to the facial skin such as wrinkles, acne, dry skin and yellow teeth, as well as an unpleasant smell, and they are precisely the reasons to encourage smoking cessation. ${ }^{13}$

Tobacco consumption also has economic consequences for its consumers, since in 2015 adult smokers in Mexico spent on average 297.2 Mexican pesos a month on manufactured cigarettes. ${ }^{9}$

\section{TOBACCO REDUCTION INTERVENTIONS}

Efforts began to be made from the 1960s to warn about the dangers of tobacco use, in the mid-20th century one of the first studies was carried out which showed the relationship between lung cancer and smoking. In 1962, a report was made by the Royal English College. Later, in 1964, the Surgeon General of the United States followed with another report, these were the first documents in which the implementation of measures to regulate tobacco use were suggested, which achieved a decrease in prevalence of smoking. ${ }^{14}$
At a global level, efforts have been made to eradicate tobacco use, the World Health Organization has proposed the plan of measures MPOWER, which stands for Monitor: monitor tobacco use and prevention policies, Protect: protect the Tobacco Smoke Population, Offer: Offer Tobacco Cessation Aid, Warn: Warn of Tobacco Dangers, Enforce: Enforce Tobacco Advertising, Promotion and Sponsorship Bans, Raise: Raise Tobacco Taxes. These measures help to tackle the tobacco epidemic and reduce the number of fatalities. ${ }^{7}$

In order to offer a treatment to those who wish to stop using tobacco or to reduce consumption, it is necessary to make a diagnosis on the severity of this, in health institutions it is considered to classify the patient with mild smoking when smoking from 1 to 5 cigarettes, moderate smoking when smoking 6 to 15 cigarettes and severe smoking when smoking more than 16 cigarettes daily. ${ }^{8}$

\section{HARM REDUCTION INTERVENTION}

Harm reduction as a care program aimed at all those subjects who consume drugs, legal or illegal, that cause damage to physical and mental health. ${ }^{15}$

The Official Mexican Standard-028-SSA2, for the prevention, treatment and control of addictions, considers harm reduction as the set of actions aimed to avoid or reduce the risks and negative consequences and thereby limit the harm associated with drug use. $^{16}$

Thus, harm reduction is identified as the set of ideas and practical strategies focused on reducing the negative consequences associated with drug use, in addition to being a movement for the respect of the rights of people who use these substances. ${ }^{17}$ This intervention model should be based on the recommendations issued by the clinical practice guidelines based on scientific evidence. As is the case of the clinical practice guideline for the prevention, diagnosis and treatment of tobacco use and second-hand smoke in the first level of care, which issues a series of recommendations especially for the Mexican adolescent population who uses tobacco or is a passive smoker, in which as preventive measures it focuses on research on consumption and factors associated with it, as well as family counselling for the reduction and elimination of consumption, in terms of intervention with adolescents with tobacco addiction, psychosocial interventions oriented towards modifications of addictive behaviours, identification of emotions associated with consumption and unhealthy lifestyles, as well as social influence and pharmacological treatments. ${ }^{18}$

\section{METHOD}

A systematic bibliographic review was carried out, searching the PubMed, Ebsco, Dialnet, ScienceDirect and Redalyc databases, as well as documents issued by public and governmental institutions and organizations.

The following objectives for the bibliographic review were established.

Primary objectives: To identify those investigations that have used the harm reduction model as an intervention for adolescents with smoking.

Secondary objectives: To identify those investigations that have used the harm reduction model as treatment of adolescents who 
consume any type of psychoactive substance, in order to estimate the effectiveness of this model.

Inclusion criteria: Original and review articles were considered studies that evaluated the effectiveness of the harm reduction model in treatment for substance use and specifically for smoking, whose study population were adolescents, studies that had a minimum sample of 10 participants, without limit of time until 2020

Exclusion criteria: case studies.

The following keywords were used: smoking, adolescence, harm reduction.

\section{RESULTS}

Few interventions with a substance use harm reduction approach targeting adolescents account for the effectiveness of this intervention model.

For the primary objective of the research, the obtained results are presented below.

One of the most widely used interventions under the harm reduction model for tobacco use refers to substitution programs, whose objective is to replace combustible cigarettes with drugs, in order to reduce the risks and negative consequences, these programs have shown scientifically significant effects for the reduction of health damage associated with some drugs. ${ }^{19}$

Table 1 shows some of the results about the effectiveness of tobacco replacement programs.

Table 1. Replacement programs to harm reduction model.

\begin{tabular}{|c|c|c|}
\hline $\begin{array}{l}\text { Type of } \\
\text { treatment for } \\
\text { harm reduction } \\
\text { due to smoking }\end{array}$ & Study objective & Results \\
\hline \multirow{3}{*}{$\begin{array}{l}\text { Patches, } \\
\text { nicotine } \\
\text { products }\end{array}$} & $\begin{array}{l}\text { To determine } \\
\text { effectiveness of nicotine } \\
\text { patch therapy in } 101 \\
\text { adolescents who smoke } \\
\text { at least } 10 \text { cigarettes } \\
\text { daily. }\end{array}$ & $\begin{array}{l}\text { Plasma cotinine levels were correlated with } \mathrm{CO} \text { levels at baseline }(\mathrm{r}=0.27 \text {; } \\
\mathrm{P}=.006), 3 \text { weeks }(\mathrm{r}=0.34 ; \mathrm{P}=.004) \text {, and } 6 \text { weeks }(\mathrm{r}=0.26 ; \mathrm{P}=.03) \text { and } \\
\text { with the average cigarettes smoked per day during } 3(\mathrm{r}=0.24 ; \mathrm{P}=.04) \text { and } 6 \\
\text { weeks }(\mathrm{r}=0.30 ; \mathrm{P}=.02) \text {. Average smoking rates decreased; however, } \\
\text { nicotine patch therapy does not appear to be effective in treating adolescent } \\
\text { smokers. }{ }^{20}\end{array}$ \\
\hline & $\begin{array}{l}\text { To determine effects of } \\
\text { the nicotine patch on } \\
\text { anxiety and withdrawal } \\
\text { symptoms, safety and } \\
\text { compliance among } \\
\text { adolescents }\end{array}$ & $\begin{array}{l}\text { Compared to the placebo patch group, the active nicotine patch group } \\
\text { experienced a significantly lower craving score and an overall withdrawal } \\
\text { symptom score }(p=.011 \text { and } p=.025 \text {, respectively), as well as a time trend } \\
\text { toward lower scores }(\mathrm{p}<.001) \text { only in craving, there was no difference in the } \\
\text { remaining variables to evaluate. } \\
\text { The point prevalence ( } 7 \text {-day and } 30 \text {-day withdrawal rates) and the } \\
\text { participants' withdrawal analysis did not indicate significant differences } \\
\text { between the treatment groups. }{ }^{21}\end{array}$ \\
\hline & $\begin{array}{l}\text { To determine the } \\
\text { effectiveness and safety } \\
\text { of the nicotine patch and } \\
\text { gum in adolescents who } \\
\text { wish to quit smoking. }\end{array}$ & $\begin{array}{l}\text { Intention-to-treat analysis of all randomized participants showed prolonged } \\
\text { CO withdrawal rates of } 18 \% \text { for the active patch group, } 6.5 \% \text { for the active } \\
\text { gum group, and } 2.5 \% \text { for the placebo group. This means that both products } \\
\text { are safe for the treatment of adolescents, especially if the patch is combined } \\
\text { with cognitive behavioural therapy. }{ }^{22}\end{array}$ \\
\hline
\end{tabular}

Source: Own elaboration

The conclusions of most of the research mentioned above indicate that the use of nicotine products to substitute the use of combustible cigarettes is not very effective, since there are no significant differences between adolescents who use the patch and those who do not, they do so in terms of tobacco use.
Similarly, substitution programs have been implemented through the use of electronic cigarettes. Table 2 shows the results of research evaluating the effectiveness of electronic cigarettes for adolescents who want to quit smoking.

Table 2. Substitution programs with electronic cigarettes for adolescents.

\begin{tabular}{|c|c|c|}
\hline $\begin{array}{l}\text { Type of } \\
\text { treatment for } \\
\text { harm reduction } \\
\text { due to smoking }\end{array}$ & Study objective & Results \\
\hline & $\begin{array}{l}\text { Longitudinal study, to } \\
\text { determine if there is a } \\
\text { potential benefit for } \\
\text { electronic cigarette } \\
\text { consumption for non- }\end{array}$ & $\begin{array}{l}9.3 \% \text { former tobacco smoker participants reported to have used e-cigarettes } \\
\text { in the past } 30 \text { days, while } 6.7 \% \text { reported to never have used, those were } \\
\text { significantly more likely to relapse to use combustible cigarettes than those } \\
\text { who had never used e-cigarettes, which represented } 1.3 \% \text {, which means }\end{array}$ \\
\hline
\end{tabular}




\begin{tabular}{|c|c|c|}
\hline \multirow{3}{*}{$\begin{array}{l}\text { E-cigarettes } \\
\text { replace } \\
\text { tobacco. }^{23}\end{array}$} & $\begin{array}{l}\text { smokers and formers } \\
\text { smokers. }\end{array}$ & $\begin{array}{l}\text { that the use of electronic cigarettes represents a risk factor for the treatment } \\
\text { of former tobacco smokers. }{ }^{24}\end{array}$ \\
\hline & $\begin{array}{l}\text { To determine the } \\
\text { association between the } \\
\text { current use of electronic } \\
\text { cigarettes and the regular } \\
\text { consumption of } \\
\text { combustible cigarettes in } \\
\text { young Americans } \\
\text { between } 12 \text { and } 17 \text { years } \\
\text { old. }\end{array}$ & $\begin{array}{l}\text { Compared to non-e-cigarette teens, current e-cigarette users (non-smokers) } \\
\text { were } 5.0(95 \% \mathrm{CI}=1.9,12.8) \text { times more likely to become regular smokers } \\
\text { of combustible cigarettes } 1 \text { year later. The use of electronic cigarettes is not } \\
\text { a harm reduction strategy, since it would have consequences contrary to } \\
\text { those that are sought to be avoided in young smokers. }{ }^{25}\end{array}$ \\
\hline & $\begin{array}{l}\text { Systematic review of } \\
\text { studies evaluating the } \\
\text { effects of nicotine. }\end{array}$ & $\begin{array}{l}\text { Research has shown that exposure to nicotine alone, as in the case of } \\
\text { electronic cigarettes, causes damage to the nervous, immune, respiratory } \\
\text { and cardiovascular systems, especially when consumed during critical } \\
\text { developmental periods such as adolescence. }{ }^{26}\end{array}$ \\
\hline
\end{tabular}

Source: Own elaboration

The results of the investigations to reduce the adverse consequences of the consumption of fuel cigarettes by replacing them with electronic cigarettes indicate that these represent a risk factor for adolescents, since users are more likely to use tobacco, in addition to nicotine itself. Which can cause damage to health. As part of the secondary objective, research evaluating the effectiveness of the harm reduction approach for drug use was summarized as mentioned below.

Proximity intervention in a community centre (outreach) is a model that fosters the possibility of community participation, which is also essential for the construction of the individual's concept of health. The evidence from outreach shows that considering the context and developing social empowerment through educational interventions, favours the quality of life of those young people who use any drug, including tobacco, reducing the negative consequences of their use. ${ }^{27}$

The National Drug Research Institute of the University of Curtin, developed an intervention with a harm reduction approach, for public high school students from 13 to 17 years old, whose objective was to reduce the negative consequences associated with alcohol consumption and also it sought to reduce the harm of those students who had not consumed alcohol but who lived with other students who did so frequently. ${ }^{28}$ In order to verify the effectiveness of this intervention, there was a control group and an experimental group, the intervention lasted 32 months, the results indicated that after the intervention the participants decreased their alcohol intake, while their knowledge regarding the consequences consumption of this substance were favored. ${ }^{29}$

Similar results report other interventions that used harm reduction strategies for alcohol consumption, mainly that of regulating the amounts of consumption, obtaining as results the normalization of biochemical parameters, histological improvement in liver disease related to alcohol consumption, as well as improvement in symptoms of anxiety and depression. ${ }^{30}$ Other research with adolescent multiple drug users who need harm reduction strategies such as avoiding the mixture of depressant drugs and setting limits on the amounts consumed per occasion, are less likely to experience negative consequences such as drastic mood changes, sexual difficulties, accidents, episodes of violence and loss of consciousness, due to the dosing-related strategies that relate to less damage in health. ${ }^{31}$
The harm reduction approach for substance use has been used to generate public policies such as increasing product taxes, prohibition of public consumption, legal minimum age to acquire legal drugs and advertising restrictions, which have proven their effectiveness in reducing drug use, consumption of alcohol and tobacco. ${ }^{32}$

Even though adolescent intervention programs are well structured and defined, there is still insufficient scientific evidence on the effectiveness of treatments for children and adolescents with smoking. This may be conditioned by the fact that it is thought that during adolescence tobacco use can be intermittent, therefore the nicotine addiction is weak, however, statistical data allow us to realize that there is a large percentage of young people that smoke. ${ }^{33}$ Research indicates that approximately three out of five young people are tobacco dependent even if they do not become daily smokers ${ }^{34}$ and that $50 \%$ of young people who smoke tobacco develop symptoms of nicotine withdrawal in their efforts to quit. ${ }^{35,36}$

\section{DISCUSSION}

In order to offer treatment to those who wish to stop using tobacco or to reduce consumption, it is necessary to make a diagnosis on its severity. In health institutions, a patient with mild smoking is classified by consuming 1 to 5 cigarettes, moderate smoking when smoking 6 to 15 cigarettes and severe smoking when more than 16 cigarettes are consumed daily. ${ }^{8}$

It is essential for any intervention related to tobacco consumption to consider the age of onset of consumption, since this increases the possibility that subjects have developed an addiction to it, so quitting this habit can become somewhat more difficult since that various factors intervene. ${ }^{4,11}$

Tobacco use during adolescence may be the first contact with drugs, which is associated with an increased risk for the consumption of other substances such as marijuana and alcohol. In addition, $97.2 \%$ of adolescent smokers use a second drug, mainly alcohol. ${ }^{37}$

The majority of adolescent smokers state that they could quit smoking at any time if they so choose to do so, which shows a lack of knowled ge about addiction and how difficult it can be to stop using tobacco. ${ }^{5}$ Various investigations have shown that when adolescents manifest a fear for their health derived from tobacco consumption, they avoid tobacco use ${ }^{6,38}$ while already 
smokers believe they have control over their consumption, which favours repeating the behaviour. ${ }^{39}$

However, most of the interventions carried out in the adolescent population are more aimed at the prevention of tobacco use and the protection of spaces free of tobacco smoke. .,36,40 $^{-1}$

Regarding the care of those young people who habitually consume tobacco or have developed an addiction, care is generalized, since the interventions in Mexico are based on the Official Mexican Standard 028-SSA2-2009 that refers to the prevention and treatment of addictions ${ }^{16}$ that recognizes smoking as a disease, which is why specialists in the subject are required to care for these subjects, where psychosocial and pharmacological factors are addressed. ${ }^{40,41}$

It should be considered that those subjects who manage to abstain from using tobacco during ad olescence will be less likely to develop an addiction, since there is a direct relationship between addiction and the beginning of consumption. ${ }^{42}$

Children and adolescents are a high-risk group that must be protected from the tobacco ind ustry, since tobacco consumption is associated with behavioral patterns derived from the aggressive tobacco industry commercial strategies, focused mainly on young people. ${ }^{3}$

In public health, harm reduction is an approach that deals with issues related to drug use and that places special emphasis on reducing the negative consequences of drug use instead of trying to eliminate drug use or ensure abstinence. ${ }^{15}$

Despite the fact that there are some interventions with a harm reduction approach, few have reported scientific evidence regarding their effectiveness.

Therefore, the first focus should be the intervention for harm reduction with adolescent tobacco users, towards information on the short, medium and long-term risks and negative consequences of habitual tobacco use, and later towards reducing the health damages derived from said consumption, which would be expected as a result of a decrease in tobacco consumption in this population group and even, through the support of a multidisciplinary team that directly intervenes in the addiction to tobacco components, which can be eliminated of people's lives, thereby increasing their quality of life. ${ }^{26,27}$

In Mexico and Latin America, public policies aimed at drug use have focused on the repression and modification of drug use, generating a model of social control based on medical, sanitary and legal precepts that stigmatize and criminalize drug use. ${ }^{19}$ Furthermore, since the lack of training and specialization of professionals to intervene in drug addiction issues with adolescents permeate, in addition to the fact that few economic resources are allocated to addiction prevention and treatment programs, there is little development of government programs under the harm reduction model and stigma and discrimination around substance use and abuse persist, the foregoing offers a field of training, updating and intervention for the activity of early detection, promotion and health education activities. ${ }^{17,40}$

\section{CONCLUSIONS}

The reasons that lead young people to start and maintain tobacco use are multifactorial.

Therefore, it is of utmost importance that countries adopt effective measures to combat the tobacco epidemic, especially in the weakest population groups. Due to the evident inequalities in health that this epidemic has accentuated, since the countries with the lowest incomes will be those with up to $80 \%$ of morbidity and mortality due to tobacco use. ${ }^{43}$

\section{REFERENCES}

1. Instituto Nacional de Psiquiatría Ramon de la Fuente Muñiz (INPRFM) et al. Encuesta Nacional de Consumo de Drogas, Alcohol y Tabaco, [ENCODAT] 2016-2017. Primera edición. México: Secretaría de Salud; 2017.

2. Secretaría de Salud. Programa de acción: Adicciones. Tabaquismo. Available from: http://www.salud.gob.mx/unidades/cdi/documentos/tabaquismo.pdf [Accessed 18 february 2020]

3. World Health Organization (WHO). WHO Report on the Global Tobacco Epidemic, 2019. Offer help quitting tobacco. Summary. Available from: https://apps.who.int/iris/bitstream/handle/10665/326072/WHO-NMHPND-2019.5-spa.pdf [Accessed 20 february 2020]

4. Martín-Suárez MA, Echevarría-García E, Sánchez-Fernández CM, Hernández-Aise MI, Triana-Pérez M, Hernández-Ruiz OA. Comportamiento del tabaquismo en los adolescentes del Reparto Fructuoso Rodríguez, Cárdenas. Rev. Med. Electron. 2015;37(6):57988.

5. Reynales LM, Rodríguez R, Ortega P, Flores MG, Lazcano E, Hernández M. Encuesta de Tabaquismo en Jóvenes 2011. Primera edición. México: Instituto Nacionalde Salud Pública; 2013.

6. Miguel-Aguilar CF, Rodríguez-Bolaños RA, Caballero M, ArilloSantillán E, Reynales-Shigematsu LM. Fumar entre adolescentes: Análisis cuantitativo y cualitativo de factores psicosociales asociados con la decisión de fumar en escolares mexicanos. Salud Pub. Mex. 2017;59(1):63-72.

7. World Health Organization (WHO). Global report on trends in prevalence of tobacco use 2000-2025. Available from: https://www.who.int/publications-detail/who-global-report-on-trendsin-prevalence-of-tobacco-use-2000-2025-third-edition [Accessed 20 february 2020]

8. Instituto Mexicano del Seguro Social (IMSS). Por tabaquismo mueren en México 135 personas al día. México: IMSS; 2018 Ava ilable from: http://www.imss.gob.mx/prensa/archivo/201805/138 [Accessed 12 de febrero de 2020].

9. Pan American Health Organization (PAHO). National Institute of Public Health (INSP). Global Adult Smoking Survey Mexico 2015. Available from: https://www.who.int/tobacco/surveillance/survey/gats/mexreport-2015-spanish.pdf [Accessed 14 february 2020].

10. Pan American Health Organization (PAHO). For a Youth Without Tobacco: Acquiring Healthy Living Skills. Available from: https://iris.paho.org/handle/10665.2/2820 [Accessed 20 february 2020].

11. González-Hidalgo JA, Díaz-Piedra JA, Alfonso-Díaz K, ÁvalosGonzález MM. Hábito de fumaren la adolescencia Rev. Cub. Med.Gen. Integr. 2012;28(3):282-89.

12. World Health Organization (WHO). WHO Report on the Global Tobacco Epidemic, MPOWER Action Plan 2008. Available from: https://www.who.int/tobacco/mpower/2008/es/ [Accessed 23 february 2020].

13. Herrera AM, Paz M. Tabaquismo en la adolescencia. Neumol. Pediatr. 2018;13(2):67-9.

14. Bianco E. Las estrategias para el control de tabaco y su racionalidad Rev. Urug. Cardiol. 2005;20:171-95.

15. Romero M, Durand AL. Abuso de sustancias adictivas en mujeres marginales. Gen. Salud. 2007;5(1):1-30.

16. Secretaría de Salud. Norma Oficial Mexicana NOM-028-SSA2-2009 Para la prevención, tratamiento y control de las adicciones. Available from: http://www.conadic.salud.gob.mx/pdfs/norma_oficial_nom.pdf [Accessed 05 march 2020] 
17. Tizoc A, Rivera K, Rieke U, Cruz M. Reducción de daños como estrategia para el uso y abuso de sustancias en México: desafíos y oportunidades. Ra. Ximhai. 2017;13(2):39-51.

18. Secretaría de Salud. Prevención, diagnóstico y tratamiento del consumo de tabaco y humo ajeno, en el primer nivel de atención. Available from: http://www.cenetec.salud.gob.mx/descarga s/gpc/CatalogoMaestro/108 -GPC_ConsumodeTabacoyhumodetabaco/SSA_108_08_EyR1.pdf [Accessed 01 march 2020]

19. Red Iberoamericana de ONG que trabajan en drogas y adicciones (RIOD). La reducción de daños en la intervención con drogas. Primera Edición. Madrid: RIOD;2018.

20. Hurt RD, Croghan GA, Beede SD, Wolter TD, Croghan IT, Patten CA Nicotine patch therapy in 101 adolescent smokers. Efficacy, withdrawal symptom relief, and carbon monoxide and pla sma cotinine levels. Arch. Pediatr. Adolesc. Med. 2000;154:31-7.

21. Hanson K, Allen S, Jensen S, Hatsukami D. Treatment of adolescent smokers with the nicotine patch. Nicotine Tob. Res. 2003;5(4):515-26.

22. Moolchan ET, Robinson ML, Ernst M, Cadet JL, Pickworth W, Heishman SJ. et al. Safety and efficacy of the nicotine patch and gum for the treatment of adolescent tobacco addic. Pediatr. 2005;115:407-14.

23. Soneji S, Barrington-Trimis JL, Wills TA, LeventhalAM, Unger JB. et al. Association Between Initial Use of e-Cigarettes and Subsequent Cigarette Smoking Among Adolescents and Young Adults: A Systematic Review and Meta-analysis. JAMA Pediatr. 2017;171(8):788-97.

24. McMillen R, Klein JD, Wilson K, Winickoff JP, Tanski S. E-Cigarette Use and Future Cigarette Initiation Among Never Smokers and Relapse Among Former Smokers in the PATH Study. Pub. Health Rep. 2019;134(5):528-33.

25. Osibogun O, Bursac Z, Maziak W. E-Cigarette use and regular ciga rette smoking among youth: population assessment of tobacco and health study (2013-2016). Am. J. Prev. Med. 2020. Available from: https://doi.org/10.1016/j.amepre.2020.01.003

26. McGrath-Morrow SA, Gorzkowski J, Groner JA, Rule AM, Wilson K. Tanski SE. Collaco JM. Klein JD. The Effects of Nicotine on Development. Pediatr. 2020;145(3):430-43.

27. Rhodes T. Outreach work with drug users: Principles and practice.Europe: Council of Europe Publishing; 1996.

28. McBride N, Midford R, Farringdon FH, Alcohol harm reduction education in schools: planning an efficacy study in Australia. Drug and Alcoh. Rev.2000;19(1):83-93.

29. McBride N, Farringdon F, Midford R. Meuleners L, Phillips M. Ham minimization in schooldrug education: final results of the School Health and Alcohol Harm Reduction Project (SHAHRP). Addict. 2004;99(3):278-91.

30. Charlet K, Heinz A. Harm reduction-a systematic review on effects of alcohol reduction on physical and mental symptoms. Addict. Biol. 2017; 22(5):1119-59.

31. Fernández-Calderón F, Díaz-Ba ta nero C, Barratt MJ, Pa la mar JJ. Harm reduction strategies related to dosing and their relation to harms among festival attendees who use multiple drugs. Drug. Alcohol Rev. 2019;38(1):57-67.

32. Medias E, Halt WD, Lynskey M, Morley KI, Reavley N, Atrang J, Palton G, Degenhardt L. Prevention, early intervention, harm reduction, and treatment of substance use in young people. Lancet Psychiat. 2016;3(3):280-96.

33. Barruecos M, Gómez G, Torrecillac M, Pérez A, Bartolomé, C. Value of brief intervention and treatments Pharmacology to stop smoking in adolescents. Arch. Bronconeumol. 2007;43(6):334-9.

34. Colby SM, Tiffany ST, Shiffman S. et al. Are adolescent smokers dependent on nicotine? A review of the evidence. Drug. Alcohol Depend. 2000;59(1):83-95.
35. Sussman S, Dent CW, Severson H, et al. Self-initiated quitting among adolescent smokers. Prev. Med. 1998;27: A19-A28.

36. Rojas NL, Killen JD, Haydel KF, Robinson TN. Nicotine dependence among adolescent smokers. Arch. Pediatr. Adolesc. Med. 1998; 152:151-6.

37. Secretaría de Salud, Dirección General de Epidemiología. Sistema de Vigilancia Epidemiológica de Adicciones, Centros de Integración Juvenil. Available from: http://www.salud.gob.mx/unidades/cdi/documentos/CDM1-4.htm [Accessed 04 march 2020].

38. Kabir MA, Goh KL, M Khan MH. Adolescent tobacco use and its determinants: Evidence from Global Youth Tobacco Survey, Bangladesh 2007. Asia Pac. J. Pub. Health. 2015;27(2):1578-90.

39. García-Rodríguez GR, Suárez-Vázquez R, Santonja-Gómez FJ, Secades-Villa R, Emilio SH. Psychosocial risk factors for adolescent smoking: A school-based study. Int. J. Clin. Health Psychol. 2011;11(1):23-33.

40. Comisión Nacional Contra las Adicciones [CONADIC]. Programa contra el Tabaquismo: Actualización 2011-2012. Available from: http://www.salud.gob.mx/unidades/cdi/documentos/tabaquismo.pdf [Accessed 07 march 2020].

41. Bello S. Tratamiento del tabaquismo. Rev. Chil. Cardiol. 2011;30(3):230-39.

42. Del Olmo R. La cara oculta de la droga.Primera edición. Bogotá: Temis S.A;1987.

43. Apia R, Kuri P, Hoy MJ. Panorama epidemiológico del tabaquismo en México. Salud. Pub. Mex. 2001;43(5):478-84. 